\title{
Pengaruh Penambahan Arang Sekam Terhadap Pertumbuhan Tanaman Kangkung Darat (Ipomoea reptans)
}

\author{
Hartati $^{1}$, Nikman Azmin ${ }^{2}$, Cisatry Emi ${ }^{3}$, Bakhtiar ${ }^{4}$, Muh.Nasir $^{5}$, Fahruddin $^{6}$, Andang $^{7}$ \\ 1,2,4,5,6, Dosen Program Studi Pendidikan Biologi STKIP Bima \\ 7Program Studi Pendidikan Matematika STKIP Bima \\ ${ }^{3}$ Mahasiswa Program Studi Pendidikan Biologi STKIP Bima \\ (E-mail: biologinikman@gmail.com)
}

\begin{abstract}
Abstrak
Upaya untuk meningkatkan produksi tanaman Ipomoea trus dilakukan, salah satu media yang dapat digunakan dalam meningkatkan produktivitas tanaman Ipomoea yaitu media arang sekam. Tujuan penelitian ini untuk mengetahui pengaruh komposisi media tanam arang sekam dan pupuk padat kotoran sapi terhadap pertumbuhan tanaman kangkung. Rancangan nlitian adalah Rancangan Acak Lengkap dengan 4 perlakuan dan 4 ulangan yaitu P0 sebagai kontrol, P1: tanah, arang sekam, kotoran sapi (1: 2: 2), P2: tanah, arang sekam, Kotoran sapi (1:3: 3) dan P3: tanggul tanah, arang sekam, kotoran padat muka sapi (1: 3: 4). Variabel yang diamati meliputi, pertumbuhan (Tinggi Tanaman, Jumlah Daun) dan produksi. Analisis data yang digunakan dengan analysis of variance. Hasil penelitian menunjukkan bahwa perlakuan berpengaruh nyata terhadap pertumbuhan dan produksi tanaman Ipomoea yang terletak pada perlakuan P3 dengan perbandingan komposisi campuran tanah dengan arang sekam, kotoran sapi (1:3:4) dengan ratarata berat basah persebaran per polybag 30.22 gram. Pertumbuhan tertinggi terletak pada perlakuan P1 dengan komposisi campuran tanah, arang sekam dan kotoran sapi (1:3:4) dengan rata-rata sebesar $28,82 \mathrm{~cm}$, sedangkan komposisi terbaik sangat berpengaruh terhadap pertumbuhan pada nilai $100 \%$ adalah perlakuan $P 3$
\end{abstract}

Kata Kunci: Arang Sekam, Pertumbuhan, Kangkung darat

\section{PENDAHULUAN}

Kegiatan pertanian yang meliputi budidaya bercocok tanam merupakan kebudayaan manusia yang paling tua. Sejalan dengan peningkatan peradaban manusia, tehnik budidaya tanaman juga berkembang menjadi berbagai sistem mulai dari sistem yang sederhana sampai dengan sistem yang canggih. Berbagai teknologi budidaya dikembangkan untuk mencapai produktivitas yang diinginkan (Irawan dan Kafiar, 2015). Pengembangan produktivitas tanaman terus dilakukan terutama pada tanaman yang tergolong holtikultural, salah satu tanaman holtikultural yang memiliki nilai ekonomis adalah Ipomoea reptans, tanaman ini dikembangkan hampir diseluruh kawasan nusantara (Naomi dkk, 2017).

Upaya untuk meningkatkan produksi tanaman Ipomoea reptans masih terusmenerus bertumpu pada perbaikan kesuburan tanah dan penggunaan media tanam yang efektif dan efesien untuk meningkatkan 
pertumbuhan tanaman. Kangkung darat menghendaki tanah yang subur, gembur banyak mengandung bahan organik dan tidak dipengaruhi keasaman tanah, tidak menghendaki tanah yang tergenang, karena akar akan mudah membusuk, membutuhkan tanah yang selalu tergenang air, yang paling penting dalam mendukung pertumbuhan tanaman adalah media tanam. Media tanam merupakan tempat tinggal atau rumah bagi tanaman, tempat tinggal yang baik adalah tempat yang dapat mendukung pertumbuhan tanaman yang dibudidayakan. Media tanam yang digunakan tidak harus menggunakan tanah, melainkan banyak media lain, yang dapat digunakan sebagai media tanam, salah satunya adalah media arang sekam (Trya dkk, 2016). Menurut Azmin \& Hartati mengatakan bahwa arang sekam adalah salah media tanam yang sangat cocok untuk meningkatkan kualitas tanah dan menyuburkan tanaman.

Penambahan bahan organik yaitu arang sekam yang dimana memiliki kemampuan menahan air yang tinggi dan porositas yang baik. Sifat ini menguntungkan jika digunakan sebagai media tanam karena mendukung perbaikan struktur tanah karena aerasi dan drainase menjadi lebih baik (Hartati, dkk, 2019) serta memiliki pH anatara 8-9 yang dapat digunakan untuk meningkatkan $\mathrm{pH}$ tanah asam dan pupuk padat kotoran sapi. Pupuk organic dari kotoran sapi mempunyai kemampuan mengubah berbagai faktor dalam tanah, sehingga menjadi faktor-faktor yang menjamin kesuburan tanah sehingga memenuhi sayarat untuk meningkatkan proses pertumbuhan tanaman kangkung (Onggo, 2017)

\section{METODE}

\section{Rancangan Penelitian}

Dalam penelitian ini menggunakan Rancangan Acak Lengkap (RAL) dengan 4 perlakuan dan 4 ulangan yaitu P0 adalah kontrol, P1: tanah campur dengan arang sekam, pupuk padat kotoran sapi (1:1:2), P2: tanah campuran arang sekam, pupuk padat kotoran sapi (1:1:3), dan P3: tanah timbunan, arang sekam, pupuk padat kotoran sapi (1:1:1)

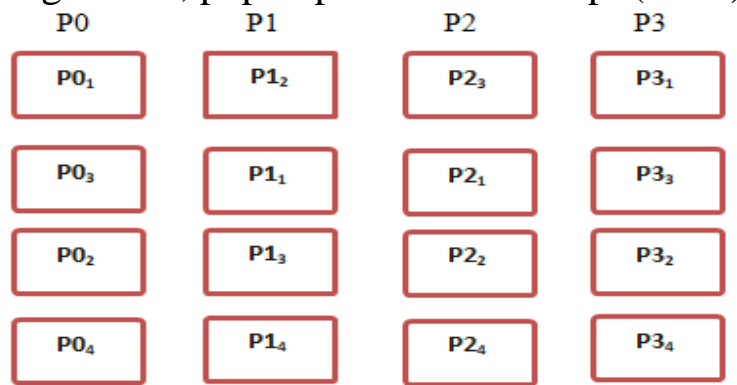

Gambar 1. Rancangan Penelitian

\section{Keterangan:}

P0 : Tanah (kontrol)

P1 :Tanah, arang sekam, pupuk padat kotoran sapi (1:2:2)

P2 :Tanah, arang sekam, pupuk padat kotoran sapi (1:3:3)

P3 :Tanah, arang sekam, pupuk padat kotoran sapi (1:3:4)

\section{Alat dan Bahan}

Alat dan bahan yang diperlukan dalam penelitian ini yaitu polybag ukuran $15 \times 20 \mathrm{~cm}$, 
penggaris $60 \mathrm{~cm}$, timbangan digital dengan nilai desimal 0,01 gram, kertas label, ayakan ukuran 5 mesh, kamera digital, gelas plastik, plastik bening, waring, bambu, tanah timbunan, media organik, benih kangkung darat dan air.

\section{Parameter Pengamatan}

Pengamatan indikator pertumbuhan yang diamati meliputi:

a. Pertumbuhan tanaman kangkung darat yang diamati terdiri dari dua parameter yaitu tinggi tanaman dan jumlah daun. Pengukuran tinggi tanaman dilakukan setiap pagi setelah penyiraman mulai hari pertama hingga tanaman berumur \pm 30 hari. Tinggi tanaman diukur mulai dari pangkal batang di atas permukaaan tanah hingga ujung daun tertinggi dengan satuan pengukuran dalam centimeter. Jumlah daun diamati setiap hari setelah penyiraman. Perhitungan jumlah daun dilakukan dengan cara menghitung jumlah daun yang telah terbuka penuh

b. Kelangsungan Hidup. Kelangsungan hidup pada tanaman kangkung dihitung dari jumlah tanaman yang hidup mulai dari awal sampai panen. Tingkat kelangsungan hidup dihitung menggunakan rumus

$$
S R=\frac{N_{t}}{N_{0}} \times 100
$$

\section{Keterangan}

SR : Kelangsungan hidup \%

$\mathrm{N}_{\mathrm{t}} \quad$ : Jumlahtanaman pada akhir penelitian

$\mathrm{N}_{\mathrm{O}}$ : Jumlahtanaman Awal Penelitian

\section{Prosedur Penelitian}

\section{Proses Persiapan Media Tanam}

Prosedur penelitian yaitu mempersiapkan semua alat dan bahan penelitian, menjemur semua media (arang sekam dan pupuk padat kotoran sapi) selama 1 minggu, menghancurkan tanah timbunan dan menghitung semua media pada ember dengan volume $\pm 4 \mathrm{~L}$ sesuai dengan perlakuan. Memasukan media kedalam polybag dan memberikan kertas label. Meletakkan polybag pada lahan dengan jarak antar polybag $30 \mathrm{~cm}$ lalu menanam tiga butir biji kangkung darat pada tiap polybag

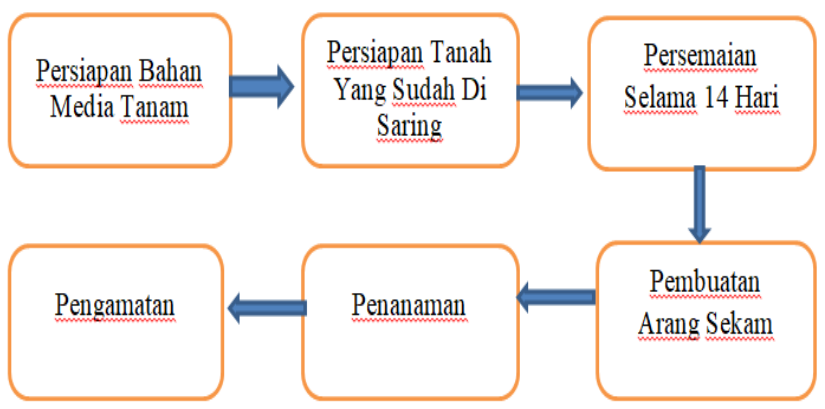

\section{Gambar 2. Alur Prosedur Penelitian}

2. Persiapan Tanah. Pengolahan tanah untuk tanaman tomat dilakukan dengan pembersihan lahan dari tanaman liar dan pembajakan tanah. Pembajakan tanah dilakukan dengan menghancurkan bongkahan-bongkahan tanah sehingga menjadi lebih halus dan lebih gembur, proses pengolahan tanah untuk lahan tomat dapat dilakukan dengan menggunakan cangkul 
3. Persemaian. Tanah persemaian terdiri dari tanah yang halus benih tanaman ditanam kedalam Media Tanam

4. Penanaman akan dilakukan dengan memasukan jumlah bibit kangkung darat dalam satu polybag yang sudah dicampur oleh tanah dengan arang sekam pada tanaman kangkung darat masing-masing 3 pohon

5. Pengamatan parameter pertumbuhan dimulai dari umur $(0,7,14,28$ dan 37) HST

\section{Analisis Data}

Data hasil penelitian dianalisis dengan menggunakan analisis ragam dan di uji lanjut dengan uji BNT pada taraf 5\%

\section{HASIL DAN PEMBAHASAN}

Pertumbuhan merupakan suatu proses perubahan ukuran organ-organ tanaman akibat adanya penambahan ukuran sel yang mencerminkan proses pertumbuhan (Azmin dkk, 2015). Keberhasilan pertumbuhan tanaman dapat ditinjau dari berbagai aspek, salah satunya adalah pertumbuhan tanaman yang dapat diamati melalui indicator pertumbuhan tanama yaitu:

\section{Pertummbuhan Tinggi}

Tinggi tanaman tertinggi ditunjukan pada perlakuan P3 dengan campuran komposisi media tanam tanah, arang sekam dan pupuk padat kotoran sapi yaitu dengan nilai rata-rata tinggi tanaman pada hari terakhir yaitu 30,22 $\mathrm{cm}$ dan rata-rata keseluruhan selisih peningkatan tinggi tanaman per hari yaitu sebesar 0,99 cm, menyusul perlakuan P2 dengan komposisi media tanam tanah, arang sekam dan pupuk padat kotoran sapi yaitu 1:3:3 yaitu dengan rata-rata tinggi tanaman pada hari terakhir yaitu $28,82 \mathrm{~cm}$ dengan rata-rata keseluruhan selisih peningkatan tinggi tanaman per hari yaitu sebesar $0,97 \mathrm{~cm}$, kemudian disusul perlakuan P3 dengan komposisi media tanam tanah timbunan, arang sekam dan pupuk padat kotoran sapi yaitu 1:3:4 dengan rata-rata tinggi tanaman pada hari terakhir yaitu 22,07 $\mathrm{cm}$ dan rata-rata keseluruhan selisih tinggi tanaman per hari yaitu sebesar $0,11 \mathrm{~cm}$, kemudian yang terakhir dengan nilai terendah yaitu perlakuan kontrol dengan rata-rata tinggi tanaman pada hari terakhir yaitu hanya $16,3 \mathrm{~cm}$ dengan rata-rata selisih peningkatan tinggi tanaman per hari yaitu sebesar 0,7 cm (Gambar 1 dan 2). 


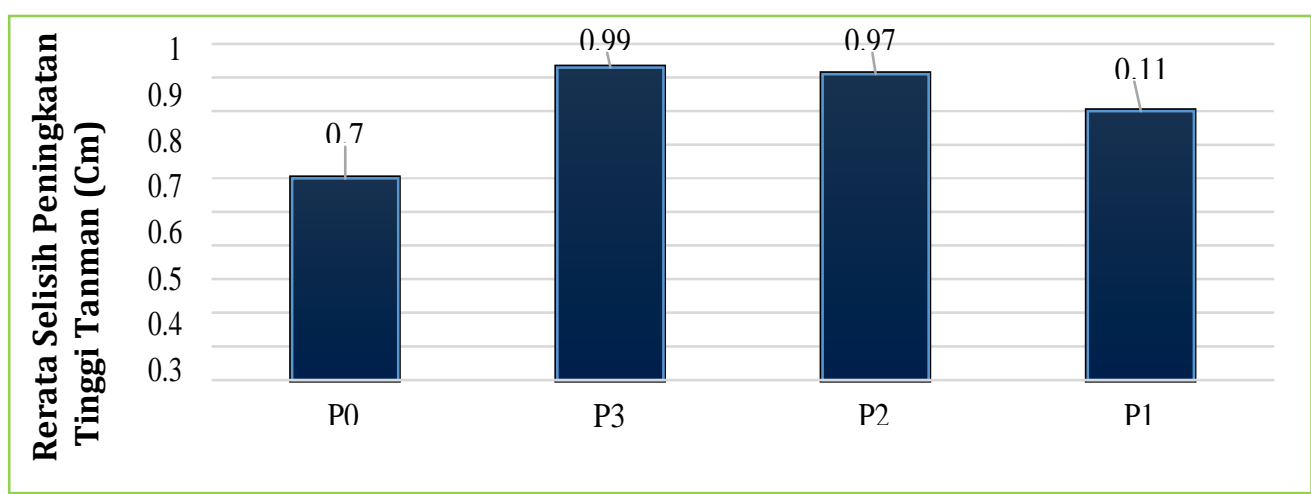

Gambar 3. Rata-rata Selisih Peningkatan Tinggi Tanaman Kangkung Darat

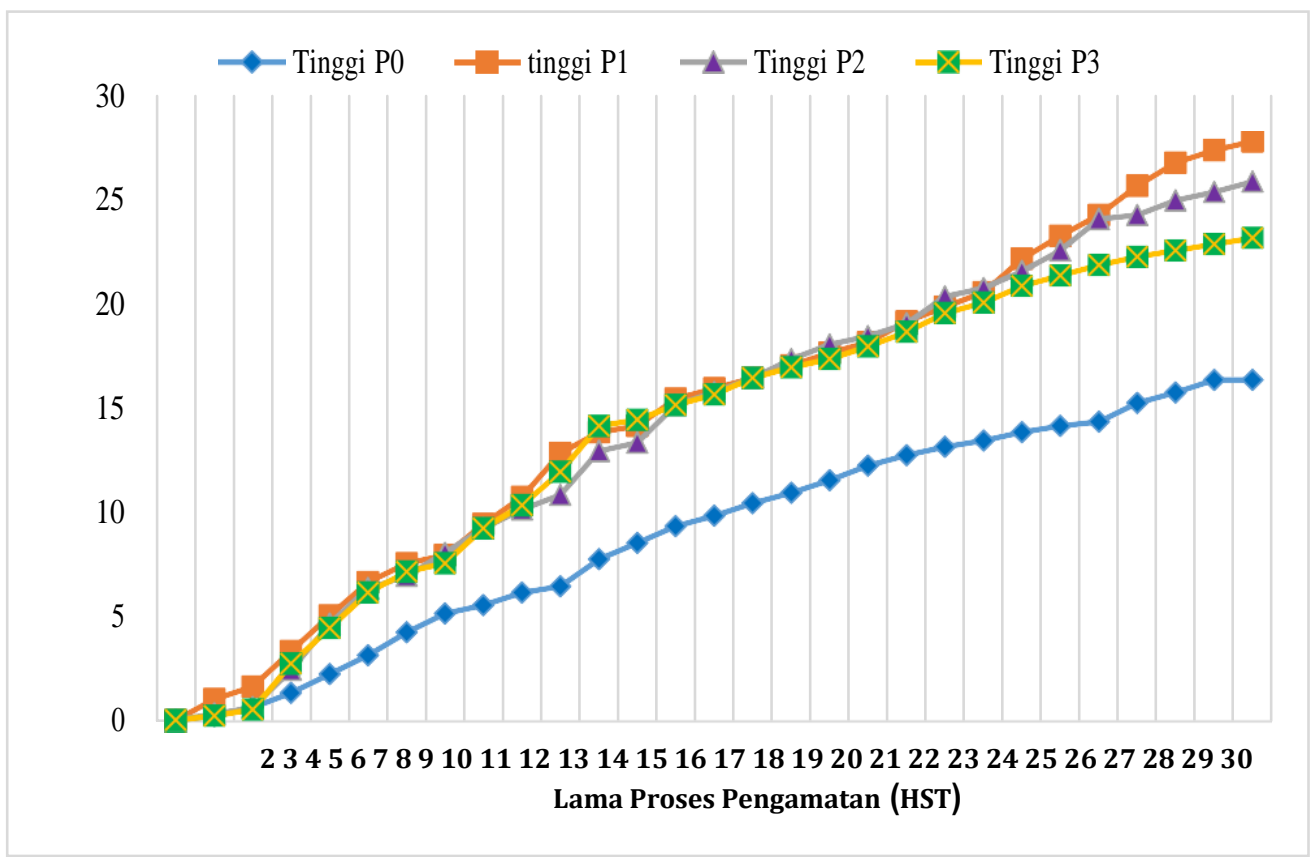

Gambar 4. Grafik Rata-Rata Peningkatan Tinggi Tanaman Kangkung Darat

Hasil penelitian juga menunjukkan pada taraf uji 5\% perlakuan P3 dengan komposisi tanah timbunan, arang sekam dan pupuk padat kotoran sapi (1:3:4) dan perlakuan P2 dengan komposisi tanah timbunan, arang sekam dan pupuk padat kotoran sapi (1:3:3) serta perlakuan P1 dengan komposisi tanah timbunan, arang sekam dan pupuk padat kotoran sapi (1:2:2) berbeda nyata dengan kontrol. Perlakuan P1 dan perlakuan P2 tidak berbeda nyata begitu pula perlakuan P2 dan P3.

Tingginya pertumbuhan tanaman kangkung pada perlakuan P3 diduga karena pada perlakuan P3 memiliki kandungan nitrogen yang paling tinggi antara keempat sampel yaitu sebesar $0,20 \%$, menyusul perlakuan P2 dengan kandungan nitrogen sebesar $0,15 \%$ dimana fungsi dari nitrogen tersebut ialah merangsang pertumbuhan 
tanaman secara keseluruhan, merupakan bagian dari sel (organ) tanaman itu sendiri berfungsi untuk sintesa asam amino dan protein dalam tanaman, serta meningkatkan kandungan metabolisme sekunder (Azmin dan Rahmawati, 2019). Selain itu Nitrogen juga merangsang pertumbuhan vegetatif tanaman seperti warna hijau pada daun, tinggi tanaman, peningkatan jumlah daun daun dan tanaman yang kekurangan unsur $\mathrm{N}$ memiliki gejala pertumbuhan lambat/kerdil, daun hijau kekuningan, daun sempit, pendek dan tegak, daun-daun tua cepat menguning dan mati (Azmin, 2015).

\section{Produksi}

Pada Tabel 1 menunjukan bahwa total rata-rata produksi tanaman kangkung darat per polybag yang terbesar yaitu terletak pada perlakuan P2 dengan komposisi media tanam tanah timbunan, arang sekam dan pupuk padat kotoran sapi 1:1:3 dengan dengan total rerata sebesar 28,625 g, menyusul perlakuan P1 dengan komposisi media tanam tanah timbunan, arang sekam dan pupuk padat kotoran sapi 1:1:2 dengan dengan total rerata sebesar 26 g, kemudian disusul perlakuan P3 dengan komposisi media tanam tanah timbunan, arang sekam dan pupuk padat kotoran sapi 1:1:1 dengan total rerata sebesar $18,9 \mathrm{~g}$ dan yang terakhir yang paling terkecil yaitu pada P0 (kontrol) dengan total rerata hanya sebesar 5,65 g. Hasil analisis ragam menunjukkan pada taraf uji 5\% semua perlakuan baik kontrol, perlakuan P1, perlakuan P2 dan perlakuan P3 memberikan pengaruh.

Tabel 1. Rata-rata Produksi Tanaman Kangkung Darat Per Polybag

\begin{tabular}{|c|l|c|c|}
\hline No & \multicolumn{1}{|c|}{ Perlakuan } & Rata-rata & Total \\
\hline P0 & Kontrol (Tanah Saja) & 5.65 & 22.6 \\
\hline P1 & Tanah Timbunan, Arang Sekam, Pupuk Padat Kotoran Sapi $(1: 1: 2)$ & 26 & 104 \\
\hline P2 & Tanah Timbunan, Arang Sekam, Pupuk Padat Kotoran Sapi $(1: !: 3)$ & 28.625 & 114.5 \\
\hline P3 & Tanah Timbunan, Arang Sekam, Pupuk Padat Kotoran Sapi $(1: 1: 1)$ & 18.9 & 75.6 \\
\hline
\end{tabular}

Tingginya produksi tanaman kangsung pada perlakuan P2 diduga disebabkan karena pada produksi (berat per polybag) dipengaruhi oleh pertumbuhan tanaman yaitu tinggi tanaman maupun jumlah daun dan semua ini tidak lepas dari kandungan unsur hara yang terdapat dalam media tanam, terutama kandungan unsur hara Kalsium dan pada perlakuan P2 memiliki kandungan kalsium cukup tinggi sebesar $8,96 \%$ dimana unsur kalsium ini memiliki salah satu fungsi yaitu memperkeras batang tanaman sehingga dapat menambah massa dari tanaman dan sekaligus merangsang pembentukan biji dan kalsium yang terdapat dalam batang dan daun dapat menetralisirkan senyawa atau suasana keasaman tanah (Azmin dkk, 2020) 


\section{KESIMPULAN}

Berdasarkan hasil penelitian bahwa perlakuan berpengaruh nyata terhadap pertumbuhan dan produksi tanaman Ipomoea pada perlakuan P3 dengan perbandingan komposisi campuran tanah dengan arang sekam, kotoran sapi (1:3:4) dengan rata-rata berat basah persebaran per polybag 30.22 gram. Pertumbuhan tertinggi pada perlakuan P1 dengan komposisi campuran tanah, arang sekam dan kotoran sapi (1:3:4) dengan ratarata $28,82 \mathrm{~cm}$, sedangkan komposisi terbaik sangat berpengaruh terhadap pertumbuhan pada nilai $100 \%$ adalah perlakuan P3

\section{DAFTAR PUSTAKA}

Azmin, N. N., \& Hartati, H. (2020). Pengaruh Pemberian Pupupk Hayati Daun Kersen Terhadap Pertmbuhan Tanaman Tomat $\begin{array}{ll}\text { (Solanum lyicopersicum L). ORYZA } & \end{array}$ Jurnal Pendidikan Biologi, 9(1), 8-14.

Azmin, N. N., Hartati, H., Nasir, M., Bakhtiar, B., \& Nehru, N. (2020). Penggunaan Media Tanam Hidroponik Terhadap Produktivitas Pertumbuhan Tanaman Terong (Solanum melongena). ORYZA Jurnal Pendidikan Biologi, 9(2), 14-20.

Azmin, N., Rahmawati, A., \& Hidayatullah, M. E. (2019). Uji kandungan fitokimia dan etnobotani tumbuhan obat tradisional berbasis pengetahuan lokal di kecamatan Lambitu kabupaten Bima. Florea: J Biol Pembelajarannya, 6, 101-113.

Azmin, N., \& Rahmawati, A. (2019). Skrining Dan Analisis Fitokimia Tumbuhan Obat Tradisional Masyarakat Kabupaten Bima. Jurnal Bioteknologi \& Biosains Indonesia (JBBI), 6(2), 259-268.

Azmin, N. (2015). Pertumbuhan Carica (Carica pubescens) Dengan Perlakuan
Dosis Pupuk Fospor Dan Kalium Untuk Mendukung Keberhasilan Transplantasi Di Lereng Gunung Lawu. EL-VIVO, 3(1). Irawan, A dan Y. Kafiar. 2015. Pemanfaatan Cocopeat dan Arang Sekam Padi Sebagai Media Tanam Bibit Cempaka Wasian (Elmerrilia Ovalis). Jurnal PROS SEMNAS MASY BIODIV INDON Volume 1, Nomor 4, Juli 2015 ISSN: 2407- 8050. Halaman: 805- 808

Hartati, H., Azmin, N., Andang, A., \& Hidayatullah, M. E. (2019). Pengaruh Kompos Limbah Kulit Kopi (Coffea) Terhadap Pertumbuhan Tanaman Kacang Panjang (Vigna sinensis L.). Florea: Jurnal Biologi dan Pembelajarannya, 6(2),71-78.

Naomi Endah Pratiwi., Bistok Hasiholan Simanjuntak, dan Dina Banjarnahor. 2017. Pengaruh Campuran Media Tanam Terhadap Pertumbuhan Tanaman Stroberi (Fragaria vesca L.) Sebagai Tanaman Hias Taman Vertikal. Jurnal AGRIC Vol. 29, No. 1, Hal: $11-20$.

Onggo, T.M. A., Kusumiyati AA. Nurfitriana . 2017. Pengaruh penambahan arang sekam dan ukuran polybag terhadap pertumbuhan dan hasil tanaman tomat kultivar 'Valouro' hasil sambung batang. Jurnal Kultivasi Vol. 16(1)

Rahmawati, N., Nasir, M., \& Ariyansyah, A. (2019). Pengaruh Pemberian Kompos Enceng Gondok (Eichornia crassipes Solm) Terhadap laju Pertumbuhan Tanaman Cabai (Capsicum frutescens L.). ORYZA (Jurnal Pendidikan Biologi), 8(1), 21-25.

Trya Juniyati., Asmah Adam., Patang .2016. Pengaruh Komposisi Media Tanam Organik Arang Sekam Dan Pupuk Padat Kotoran Sapi Dengan Tanah Timbunan Terhadap Pertumbuhan Dan Kelangsungan Hidup Tanaman Kangkung Darat (Ipomea reptans Poir). Jurnal Pendidikan Teknologi Pertanian, Vol. 2, Hal: 9-15. 